\title{
A challenge in distinguishing between acute hepatitis B and acute exacerbation of chronic hepatitis B
}

\author{
Yang-Hyun Baek \\ Department of Internal Medicine, Dong-A University College of Medicine, Busan, Korea
}

Dear Editor,

I have interestingly read the article entitled "The dilemma of differentiating between acute hepatitis B and chronic hepatitis B with acute exacerbation: Is quantitative serology the answer?" by Lall et al.'

It is difficult to distinguish between acute hepatitis B (AHB) and acute exacerbation of chronic hepatitis B (CHB-AE) as the two conditions have very similar clinical, biochemical, and serological findings. However, since the two conditions differ in their treatment strategy, prognosis, and impact on the public health, it is very important to distinguish them from one another. In this study, the authors suggested the value of 20.5 signal-to-cutoff (S/CO) of IgM anti-HBC can be used to differentiate between AHB and CHB-AE. However, before interpreting and applying these results in clinical practice, several issues should be kept in mind.

IgM anti-HBc has been traditionally considered as a specific marker of $A H B$, since its detection is observed at high levels during primary immune response after $\mathrm{HBCAg}$ interaction with immune cells. ${ }^{2}$ Recently, the introduction of assays with high sensitivity has made it possible to detect low levels of IgM anti-HBC in CHB-AE. ${ }^{3}$ Therefore, high levels of IgM anti-HBC may be suggestive of $A H B$, whereas low levels may suggest CHB-AE. However, currently available data on differentiating AHB from CHB-AE are not only limited, but they are also not robust and have variations in differentiating criteria or assays in each study. For example, Lall et al.' defined the CHB-AE group as a case of HBsAg lasting for more than 6 months, while Kumar et al. ${ }^{2}$ defined it differently as a case of HBsAg lasting for at least 12 months, along with the development of clinical, biochemical, radiologic, or histologic evidence of chronic liver disease on follow-up. Ethnics, hepatitis B virus (HBV) genotype, and individualized immune response can also affect IgM anti-HBc levels, making it difficult to determine the standardized cut-off index for distinguishing between AHB and CHB-AE.

Most studies defined a group of AHB as patients who do not show progress to chronic liver disease. Since the degree of hepatic fibrosis by elastography or serological markers can be significantly influenced by liver damage, some authors proposed that fibrosis test should be postponed for at least 3 months after stabilization of alanine aminotransferase (ALT) or acute flare in order to restore its reliability. ${ }^{4,5}$ In this study, only baseline aspartate aminotransferase (AST)/ALT ratio and AST to platelet ratio index were analyzed; however, continuous changes in follow-up after stabilization could be more clinically meaningful.

Several studies have introduced the analysis of serologic markers, including IgM anti-HBC and their kinetics, as a helpful test for distinguishing between AHB and CHB-AE., ${ }^{1,26-11}$ Table 1 summarizes the proposed discriminant factors from published studies to date.

\section{Abbreviations:}

AFP, alph-fetoprotein; AHB, acute hepatitis B; ALT, alanine aminotransferase; AST aspartate aminotransferase; $A V T$, anti-viral therapy; $C H B-A E$, acute exacerbation of chronic hepatitis B; HBV, hepatitis B virus; S/CO, signal-to-cutoff

\section{Corresponding author : Yang-Hyun Baek}

Department of Internal Medicine, Dong-A University College of Medicine 32 Daesingongwon-ro, Seo-gu, Busan 49201, Korea

Tel: +82-51-240-2728, Fax: +82-51-240-2087

E-mail: p100100@dau.ac.kr

https://orcid.org/0000-0002-9073-9233 
Table 1. Various studies on differentiation between $A H B$ and CHB-AE

\begin{tabular}{|c|c|c|c|c|c|c|c|}
\hline Study & Patient & Differential factor & Cut-off index & Tendency & Method/assay & Sensitivity & Specificity \\
\hline $\begin{array}{l}\text { Kumar et al. }^{2} \\
\text { (retrospective; 2006/ } \\
\text { India) }\end{array}$ & $\begin{array}{l}\text { AHB }(n=49) \\
\text { CHB-AE }(n=30)\end{array}$ & $\begin{array}{l}\text { lgM anti-HBC } \\
\text { HBV-DNA }\end{array}$ & $\begin{array}{l}>1: 1,000 \\
<0.5 \mathrm{pg} / \mathrm{mL}\end{array}$ & $\begin{array}{l}\mathrm{AHB} \\
\mathrm{AHB}\end{array}$ & $\begin{array}{l}\text { MEIA } \\
\text { Hybrid capture }\end{array}$ & $\begin{array}{l}77.6 \% \\
95.9 \%\end{array}$ & $\begin{array}{c}70 \% \\
86.6 \%\end{array}$ \\
\hline $\begin{array}{l}\text { Huang et al. }{ }^{6} \\
\text { (retrospective; 2006/ } \\
\text { Taiwan) }\end{array}$ & $\begin{array}{l}\text { AHB }(n=20) \\
\text { CHB-AE }(n=22)\end{array}$ & IgM anti-HBC & $>2.4-2.5 \mathrm{~S} / \mathrm{CO}$ & $A H B$ & AXSYM CORE-M & $\begin{array}{l}2.42(90 \%) \\
2.46(85 \%)\end{array}$ & $\begin{array}{l}2.42(86 \%) \\
2.46(90 \%)\end{array}$ \\
\hline $\begin{array}{l}\text { Rodella et al. } \\
\text { (retrospective; 2006/ } \\
\text { Italy) }\end{array}$ & $\begin{array}{l}\text { AHB }(n=36) \\
\text { CHB }(n=40)\end{array}$ & $\begin{array}{l}\text { IgM anti-HBC } \\
\text { IgG avidity index }\end{array}$ & $\begin{array}{l}>10 \mathrm{~S} / \mathrm{CO} \\
\geq 0.7\end{array}$ & $\begin{array}{l}\mathrm{AHB} \\
\mathrm{CHB}\end{array}$ & $\begin{array}{l}\text { CLIA } \\
\text { AxSYM assay }\end{array}$ & $\begin{array}{l}100 \% \\
98.9 \%\end{array}$ & $\begin{array}{c}98.9 \% \\
99 \%\end{array}$ \\
\hline $\begin{array}{l}\text { Han et al. }{ }^{8} \text { (retrospective } \\
\text { \& prospective; 2008/ } \\
\text { China) }\end{array}$ & $\begin{array}{l}\text { AHB }(n=138) \\
\text { CHB-AE }(n=133)\end{array}$ & $\begin{array}{l}\text { IgM anti-HBC } \\
\text { HBV-DNA } \\
\text { AFP } \\
\text { IgM anti-HBC with } \\
\text { HBV-DNA }\end{array}$ & $\begin{array}{l}>1: 10,000 \\
<10^{5} \text { copies } / \mathrm{mL} \\
\text { elevated AFP }\end{array}$ & $\begin{array}{c}A H B \\
A H B \\
C H B-A E\end{array}$ & $\begin{array}{l}\text { EIA } \\
\text { PCR method } \\
\text { ECLIA }\end{array}$ & $\begin{array}{l}96.2 \% \\
98.9 \%\end{array}$ & $\begin{array}{c}93.1 \% \\
99 \%\end{array}$ \\
\hline $\begin{array}{l}\text { Dao et al. }{ }^{9} \text { (prospective; } \\
\text { 2012/US ALF) }\end{array}$ & $\begin{array}{l}\text { AHB-ALF }(n=60) \\
\text { CHB-ALF }(n=27)\end{array}$ & $\begin{array}{l}\text { lgM anti-HBC } \\
\text { HBV-DNA }\end{array}$ & $>5 \mathrm{~S} / \mathrm{CO}$ & AHB-ALF & $\begin{array}{l}\text { IgM capture } \\
\text { immunoassay } \\
\text { PCR method }\end{array}$ & $86 \%$ & $89 \%$ \\
\hline $\begin{array}{l}\text { Park et al. } \\
\text { (retrospective; 2015/ } \\
\text { Korea) }\end{array}$ & $\begin{array}{l}\text { AHB }(n=53) \\
\text { CHB-AE }(n=29)\end{array}$ & $\begin{array}{l}\text { IgM anti-HBC } \\
\text { HBV-DNA } \\
\text { IgM anti-HBc with } \\
\text { HBV-DNA }\end{array}$ & $\begin{array}{l}\geq 8 \mathrm{~S} / \mathrm{CO} \\
<5.5 \log _{10} \mathrm{IU} / \mathrm{mL}\end{array}$ & $\begin{array}{l}A H B \\
A H B\end{array}$ & $\begin{array}{l}\text { CLIA } \\
\text { PCR method }\end{array}$ & $\begin{array}{l}96.2 \% \\
81.1 \% \\
98.1 \%\end{array}$ & $\begin{array}{l}89.7 \% \\
72.4 \% \\
86.2 \%\end{array}$ \\
\hline $\begin{array}{l}\text { Thanage et al. }{ }^{11} \\
\text { (prospective; 2019/ } \\
\text { India) }\end{array}$ & $\begin{array}{l}\text { AHB }(n=26) \\
\text { CHB-AE }(n=14)\end{array}$ & $\begin{array}{l}\text { IgM anti-HBc } \\
\text { HBV-DNA }\end{array}$ & $\begin{array}{l}\geq 12.14 \mathrm{~S} / \mathrm{CO} \\
>15,390 \mathrm{IU} / \mathrm{mL}\end{array}$ & $\begin{array}{c}\text { AHB } \\
\text { CHB-AE }\end{array}$ & $\begin{array}{l}\text { CLIA } \\
\text { PCR method }\end{array}$ & $\begin{array}{l}76.9 \% \\
78.6 \%\end{array}$ & $\begin{array}{l}71.4 \% \\
46.2 \%\end{array}$ \\
\hline $\begin{array}{l}\text { Lall et al.' (retrospective; } \\
\text { 2020/India) }\end{array}$ & $\begin{array}{l}\text { AHB }(n=89) \\
\text { CHB-AE }(n=83)\end{array}$ & $\begin{array}{l}\text { IgM anti-HBC } \\
\text { PT-INR }\end{array}$ & $\begin{array}{l}>20.5 \mathrm{~S} / \mathrm{CO} \\
<1.27\end{array}$ & $\begin{array}{l}\mathrm{AHB} \\
\mathrm{AHB}\end{array}$ & CLIA & $93.3 \%$ & $92.7 \%$ \\
\hline
\end{tabular}

$A H B$, acute hepatitis $B$; CHB-AE, acute exacerbation of chronic hepatitis; HBV, hepatitis $B$ virus; MEIA, microparticle enzyme immunoassay; CLIA, chemiluminescent immunoassay; AFP, alpha-fetoprotein; EIA, enzyme immunoassay; PCR, polymerase chain reaction; ECLIA, electro-chemiluminescence immunoassay; ALF, acute liver failure; PT-INR, prothrombin time-international normalized ratio.

Avidity index of IgG anti-HBC suggests a useful factor in the differential diagnosis of AHB and CHB-AE. ${ }^{7}$ IgG avidity is defined as the strength with which $\lg G$ binds to antigenic epitopes expressed by a given protein, which increases as IgG matures. Rodella et al. ${ }^{7}$ reported that an anti-HBC avidity index $<0.7$ indicated the possibility for AHB. Although IgG avidity index may be helpful, its standardized technique and clinical use are still limited.

Some studies suggested that serum HBV-DNA levels are lower in AHB than in CHB-AE, although no significant difference was demonstrated in this study. ${ }^{1,28-11}$ Lower levels of HBV-DNA in AHB indicated that they have been controlled by appropriate immune response from incubation period, while high levels of virus exist under insufficient immune control in CHB. However, viral replication could show various levels, and it is difficult to set a standardized cut-off level of serum HBV-DNA. It might be helpful to monitor DNA kinetics with viral replication for differential diagnosis.
Han et al. ${ }^{8}$ showed that elevated alpha-fetoprotein (AFP) were found in fewer patients with AHB than in those with CHB (26.1\% vs. $63.2 \%$ ). They hypothesized that hepatocyte necroinflammation can trigger elevation of AFP levels with fibrosis or cirrhosis already present.

In summary, high IgM anti-HBc titer, low IgG anti-HBC avidity index, low serum HBV-DNA, HBV-DNA kinetics of rapid decline, and low AFP level suggest the probability of AHB rather than CHB-AE; however, there is still insufficient evidence to present a standardized cut-off value for differential diagnosis.

Herein, I came across a patient who was difficult to distinguish as having AHB or CHB-AE. He was a 38-year-old man who presented to the emergency room with jaundice. The patient was a South Korean resident living in Vietnam, who had arrived in South Korea 2 months ago. He had no history of previous viral hepatitis, blood transfusion, surgery, dental procedures, tattooing, high-risk 
sexual behavior, or intravenous drug use. However, his mother had CHB. His laboratory findings were as follows: AST, 1,265 U/L; ALT, 1,961 U/L; total bilirubin, $21.7 \mathrm{mg} / \mathrm{dL}$; direct bilirubin, $13.9 \mathrm{mg} / \mathrm{dL}$; prothrombin time, 12.2 seconds; and international normalized ratio, 1.06. He tested positive for HBsAg, IgM anti$H B C$, and $H B e A g$ with negativity for hepatitis $A$, hepatitis $C$, hepatitis $D$, and hepatitis $E$. IgM anti-HBC by chemiluminescent immunoassay was $6 \mathrm{~S} / \mathrm{CO}$, and HBV-DNA titer was $906,844 \mathrm{IU} / \mathrm{mL}$. It was very difficult to differentiate AHB from CHB-AE. We decided to start anti-viral therapy (AVT) based on the history of his mother's hepatitis B and low IgM anti-HBc titer with high DNA viral load. The patient's symptoms and laboratory findings improved day by day; and since he had to leave for Vietnam again, he visited our hospital only twice after discharge. The patient's HBV-DNA was negative 3 weeks after the AVT began, and HBeAg was negative on the first outpatient visit. HBsAg seroconversion was also achieved in his second visit; therefore, the HBsAg loss accompanied by a rapid decline of HBV-DNA suggested AHB rather than CHB-AE, despite low IgM anti-HBC and high viral load on admission.

In South Korea, the overall prevalence of HBsAg decreased to $3 \%$ after the introduction of the national immunization program for HBV and perinatal transmission prevention program. ${ }^{12}$ Despite the low prevalence rate, unvaccinated people may be vulnerable to $A H B$, and the vaccination rate for patients with $A H B$ from 2012-2017 was actually less than 10\%. Focusing on effective and implementable prevention strategy for HBV is more preemptive than distinguishing between AHB and CHB-AE.

\section{Author's contribution}

Yang-hyun Baek contributed to analysis of data, concept of design and writing the manuscript.

\section{Conflicts of Interest}

The author has no conflicts to disclose.

\section{REFERENCES}

1. Lall S, Agarwala P, Kumar G, Sharma MK, Gupta E. The dilemma of differentiating between acute hepatitis B and chronic hepatitis B with acute exacerbation: is quantitative serology the answer? Clin Mol Hepatol 2020;26:187-195.

2. Kumar M, Jain S, Sharma BC, Sarin SK. Differentiating acute hepatitis $B$ from the first episode of symptomatic exacerbation of chronic hepatitis B. Dig Dis Sci 2006;51:594-599.

3. Milich DR, McLachlan A. The nucleocapsid of hepatitis B virus is both a T-cell-independent and a T-cell-dependent antigen. Science 1986;234:1398-1401.

4. Wong GL, Wong VW, Choi PC, Chan AW, Chim AM, Yiu KK, et al. Increased liver stiffness measurement by transient elastography in severe acute exacerbation of chronic hepatitis B. J Gastroenterol Hepatol 2009;24:1002-1007.

5. Park H, Kim SU, Kim D, Kim DY, Ahn SH, Han KH, et al. Optimal time for restoring the reliability of liver stiffness measurement in patients with chronic hepatitis B experiencing acute exacerbation. J Clin Gastroenterol 2012;46:602-607.

6. Huang YW, Lin CL, Chen PJ, Lai MY, Kao JH, Chen DS. Higher cut-off index value of immunoglobulin $\mathrm{M}$ antibody to hepatitis $\mathrm{B}$ core antigen in Taiwanese patients with hepatitis B. J Gastroenterol Hepatol 2006;21:859-862.

7. Rodella A, Galli C, Terlenghi L, Perandin F, Bonfanti C, Manca N. Quantitative analysis of $\mathrm{HBsAg}, \operatorname{lgM}$ anti-HBC and anti-HBC avidity in acute and chronic hepatitis B. J Clin Virol 2006:37:206-212.

8. Han Y, Tang Q, Zhu W, Zhang X, You L. Clinical, biochemical, immunological and virological profiles of, and differential diagnosis between, patients with acute hepatitis B and chronic hepatitis B with acute flare. J Gastroenterol Hepatol 2008;23:1728-1733.

9. Dao DY, Hynan LS, Yuan HJ, Sanders C, Balko J, Attar N, et al. Two distinct subtypes of hepatitis $B$ virus-related acute liver failure are separable by quantitative serum immunoglobulin $M$ anti-hepatitis B core antibody and hepatitis B virus DNA levels. Hepatology 2012:55:676-684.

10. Park JW, Kwak KM, Kim SE, Jang MK, Kim DJ, Lee MS, et al. Differentiation of acute and chronic hepatitis B in IgM anti-HBc positive patients. World J Gastroenterol 2015;21:3953-3959.

11. Thanage R, Rathi P, Pawar V, Udgirkar S, Jain S, Contractor Q, et al. Factors differentiating acute hepatitis $B$ from acute exacerbation of chronic hepatitis B in prospective-retrospective cohort. J Assoc Physicians India 2019;67:39-43.

12. Korean Association for the Study of the Liver (KASL). KASL clinical practice guidelines for management of chronic hepatitis B. Clin Mol Hepatol 2019;25:93-159. 